\begin{tabular}{|c|c|c|c|}
\hline Article Info & RESEARCH ARTICLE & ARAŞTIRMA MAKALESİ & \\
\hline Title of Article & \multicolumn{2}{|c|}{$\begin{array}{c}\text { Examination of Visual Pollution in Central } \\
\text { Business District: The Case of Balıkesir } \\
\text { Central Business District }\end{array}$} & \\
\hline $\begin{array}{l}\text { Corresponding } \\
\text { Author }\end{array}$ & \multicolumn{2}{|c|}{$\begin{array}{l}\text { Alper UZUN } \\
\text { Balıkesir Üniversitesi Fen-Edebiyat Fakültesi Coğrafya Bölümü, auzun@balikesir.edu.tr }\end{array}$} & \\
\hline $\begin{array}{l}\text { Received Date } \\
\text { Accepted Date }\end{array}$ & \multirow{2}{*}{\multicolumn{2}{|c|}{$\begin{array}{l}\text { 17.05.2020 } \\
05.06 .2021 \\
\text { https://doi.org/10.356 } \\
\end{array}$}} & \\
\hline DOI Number & & & \\
\hline Author / Authors & $\begin{array}{l}\text { Alper UZUN } \\
\text { Rafet YİĞIT }\end{array}$ & $\begin{array}{l}\text { ORCID: 0000-0002-1304-1683 } \\
\text { ORCID: } 0000-0002-8976-4327\end{array}$ & \\
\hline How to Cite & \multicolumn{2}{|c|}{$\begin{array}{l}\text { UZUN, A. and YİĞİT, R. (2021). Merkezi İş Alanlarındaki Görsel Kirliliğin } \\
\text { İncelenmesi: Balıkesir Merkezi İs Alanı Örneği, Kent Akademisi, Volume, 14, Issue 2, } \\
\text { Pages; 300-314 }\end{array}$} & $\begin{array}{l}\text { Kent Akademisi } \\
\text { Urban Academy }\end{array}$ \\
\hline
\end{tabular}

\title{
Merkezi İş Alanlarındaki Görsel Kirliliğin İncelenmesi: Balıkesir Merkezi İş Alanı Örneği
}

\begin{abstract}
:
The aim of this research is to determine the elements that cause visual pollution in the Central Business Area of Balıkesir city and to evaluate the findings. In this research, the qualitative research method was adopted because it has a flexible approach that varies depending on the way it handles the subject. A table of factors causing visual pollution has been created by examining the literature on the research subject. Taking into account this table, field studies were carried out in the central business area of Balıkesir city. Observations made during field studies were supported by photographs taken and data of the research was created. Data from field studies are organized under the heading visual pollution types. When pollution elements obtained from literature and field studies are evaluated according to the number of pieces they have in the table, a total of 38 pollution elements were processed in the table, including a maximum of 10 equipment, 8 other, 7 infrastructure and superstructure, 7 indirect and 6 building categories respectively. The business volume in the central business area of Balikesir city, especially the service sectors, has increased significantly. These developments have led to more intensive use of the central business area by individuals. The increase in the number of users and heavy use caused it to become crowded and the squares and sidewalks to become inadequate. This result confirms the "assumption that it has vertical development and continuity in space, that individual and collective uses are excessive, and that more effects can be seen in a visual sense" put forward in the selection of the research site.
\end{abstract}

KEYWORDS: Visual Pollution, Visual Distortion, Environmental Problems, Central Business District, Balıkesir

${ }^{1}$ Balıkesir Üniversitesi, Fen-Edebiyat Fakültesi, Coğrafya Bölümü, auzun@balikesir.edu.tr

${ }^{2}$ Balıkesir Üniversitesi, Sosyal Bilimler Enstitüsü, Coğrafya Anabilim Dalı, rafetyigit64@gmail.com 


\section{ÖZ:}

$\mathrm{Bu}$ araştırmanın amacı; Balıkesir kenti merkezi iş alanında görsel kirliliğe neden olan unsurların belirlenmesi ve ortaya çıkan bulguların değerlendirilmesidir. Bu araştırmada, konuyu ele alış biçimine göre değişen esnek bir yaklaşıma sahip olmasından dolayı nitel araştırma yöntemi benimsenmiştir. Araştırma konusu ile ilgili literatür incelenerek görsel kirliliğe yol açan faktörlerin tablosu oluşturulmuştur. Bu tablo dikkate alınarak Balıkesir kenti merkezi iş alanında saha çalışmaları gerçekleştirilmiştir. Saha çalışmaları sırasında yapılan gözlemler çekilen fotoğraflar ile desteklenmiş ve araştırmanın verileri oluşturulmuştur. Saha çalışmalarından elde edilen veriler görsel kirlilik türleri başlığı altında düzenlenmiştir. Literatürden ve saha çalışmalarından elde edilen kirlilik unsurları tabloda sahip oldukları adet sayısına göre değerlendirildiğinde sirasıyla en fazla 10 adet donatı, 8 adet diğer, 7 adet altyap v ve üstyapı, 7 adet dolaylı ve 6 adet yapı kategorisinde olmak üzere toplamda 38 adet kirlilik unsuru tabloya işlenmiştir. Balıkesir kenti merkezi iş alanındaki iş hacmi, özellikle hizmete yönelik sektörler, önemli derecede artmıştır. Bu gelişmeler merkezi iş alanının bireyler tarafından daha yoğun kullanılmasına neden olmuştur. Kullanıcı sayısının artması ve yoğun kullanım ise kalabalıklaşmaya, meydanların ve kaldırımların yetersiz kalmasına neden olmuştur. Ulaşılan bu sonuç araştırma sahasının seçilmesinde öne sürülen "mekânda dikey gelişime ve sürekliliğe sahip olması, bireysel ve toplu kullanımların fazla olması ve görsel anlamda daha fazla etkinin görülebilecek olması varsayımı"nı doğrular niteliktedir.

ANAHTAR KELIMELER: Görsel Kirlilik, Görsel Bozulma, Çevre Sorunları, Merkezi İş Alanı, Balıkesir

\section{GİRIŞ:}

Çevre kirlenmesi/bozulmasi; çevrenin sahip olduğu bileşenlerin niteliğinin değişmesi ve değerini yitirmesi ile ortaya çıkan sorunlar şeklinde ifade edilmektedir (Akın, 2009; Öğütveren, 2016). Başka bir ifade ile çevre kirlenmesi/bozulması, "Her türlü madde ya da 1S1, ses gibi enerjinin doğal birikiminin çok üstündeki miktarlarda çevreye katılmasıdır." (Güney, 2004, s. 283). Çevre sorunlarının artmasında; nüfus artışı, plansız sanayileşme, plansız/düzensiz kentleşme, enerji üretimi, kaynakların aşırı kullanımı ve haksız tüketim gibi unsurların sonucunda atık miktarının artması ve önlem alınmadan atıkların alıcı ortamlara bırakılması gibi nedenler etkili olmaktadır (Akın, 2009; Güney, 2004; Görmez, 2003; Öğ̈̈tveren, 2016; Voronych, 2013; Yılmaz ve Sağsöz, 2011).

Kentler, daha fazla nüfus miktarına ve yoğunluklarına sahip olmalarından dolayı diğer yerleşim birimlerine göre çevre sorunlarının daha yoğun olarak yaşandığı mekânlar olarak karışımıza çıkmaktadır. Kentleşme hızının artmasına paralel olarak, nüfusun bir bölgede yoğunlaşması sonrası artan yapı yoğunluğu, düzensiz yapılaşma ve gecekondu görünümleri kirliliğin başlıca elemanları olmaktadır (Güney, 2004; Yılmaz, Bulut ve Alper, 2002). Ayrıca kentlerde, kent planlamalarının da yeterince yapılmaması veya uygulanmaması da çevre kirlenmelerinin oluşmasına neden olabilmektedir (Önder ve Konaklı, 2002). Yaşanılan çevredeki düzen, uyum ve güzellik, insanlara daha sağlıklı ve yaşanabilir çevre sunmasına olanak sağlamaktadır (Bankole, 2013). Aynı zamanda bireyin ihtiyaçlarının da karşılandığı, düzenli, sağlıklı ve yaşanabilir mekânların oluşturulması kent ve bölge planlamasının da temel amacını oluşturmaktadır (Türk, 2003). Bundan dolayı kent ve bölge planlaması; kalkınmada ve gelişmede önemli olduğu kadar, mekânda görsel kirliliğin azaltılmasında ve mekânın görsel kalitesinin arttırılmasında da önem arz etmektedir. Şehirlerin, zamansal ve mekânsal olarak süreklilik arz edecek şekilde değişmesi ve gelecek dönemde de artacak olması, şehirlerin ve mekânların sürekli olarak planlanmasını ve denetlenmesini zorunlu bir ihtiyaç olarak ortaya çıkarmakta ve bunun sağlıklı ve doğru bir şekilde gerçekleştirilmesinde şehir ve bölge planlamasının gerekliliği ortaya çıkmaktadır (Keleş, 1987).

Çeşitli kirlilik türleri bulunmaktadır. Bu kirlilik türlerinden en çok dikkate alınanları hava, su ve toprak kirlilikleridir. Çünkü bu üç unsurda insanoğlu için hayati öneme sahip olan doğal kaynaklardır (Görmez, 2003; Elena, Cristian ve Suzana, 2012). Özellikle Sanayi Devrimi'nden itibaren insanoğlu ve doğal çevresi arasındaki ilişkinin giderek daha da kopması bu kirlilik türlerine birçok yeni kirlilik türlerinin eklenmesine neden olmuştur. Örneğin gürültü, görüntü/görsel, elektromanyetik, nükleer, atıklar, flora-fauna, kültürel çevre, besin ve ışık kirlenmesi gibi yaşadığımız çevrede var olan ama farkında olmadığımız farklı kirlilik türleri de bulunmaktadır (Akın, 2009; Güney, 2004; Keleş ve Hamamcı, 1998; Öner, 2016).

Görsel kirlilikle ilgili literatürde farklı tanımlar bulunmaktadır. Literatürde konu, görüntü kirliliği veya görsel kirlilik şeklinde ele alınmaktadır. Görüntü kelimesi "Gerçekte var olmadığı halde varmış gibi görünün şey, hayalet” şeklinde tanımlanmaktadır (TDK, 2020). Görsel kelimesi ise "Görme duyusuyla ilgili olan, görmeye dayanan" olarak ifade 
edilmektedir (TDK, 2020). Görsel/Görüntü kirliliğinde kirlilik, görme duyusuyla ilgili bir konu olduğu için, bu araştırmada görsel sözcüğünün kullanımının daha uygun olacağı düşünülmüştür.

Güney'e göre görsel kirlilik, "Fiziki çevre ve insanla ilgili eşyanın insan eliyle doğal çevre ve insan tabiatıyla uyumsuz ve sağlıklı insanları rahatsız edici hale getirilmesidir" (Güney, 2002, s. 248). Başka bir tanıma göre "Kişinin manzara veya manzaradan zevk alma yeteneğine zarar veren kirliliğin etkilerine değinen görsel bir konudur." (Banerjee, 2017, s. 4768). Görsel kirlilik ile birlikte çevrenin sahip olduğu fiziki yapıda meydana gelen göze hoş gelmeyen görüntüler; kent içi elemanların fonksiyonlarının engellenmesine ve insanlar üzerinde olumsuz psikolojik etkilerin oluşmasına neden olmaktadır (Bölükoğlu, 2003). Görsel kirlilik kavramı öznel bir yapıya sahip olan bir kavram olmasına karşın; çevrede yer alan düzensiz ve tutarsız desenler, karışıklık, yan yana dizilmiş olan görsel öğeler, belirli şekil ve renklerin baskınlığı gibi durumlar genellikle görsel kirlilik konusunda ön plana çıkan unsurlardır. Bu açıdan ele alındığında; genelde çevrede ve insan yapısı unsurlardaki algılama ve mutlu olma hissi üzerindeki olumsuz etkilerini tanımlamak amacıyla görsel kirlilik kavramı kullanılmaktadır (Anciaes, 2015, s. 1709).

Kent içerisinde görsel kirlenmeyi arttıran etkiler bulunmaktadır. Bu etkiler, kentte yaşayan bireyler tarafından, kenti "sahiplenme" ama "benimsememe" duyguları ile güzellik arayışları içinde bulunmamaları, kent içerisinde görsel kirlenmeyi arttıran etkiler arasında yer almaktadır (Bölükoğlu, 2003). Bu duyguların oluşmasında, bireyin zihninde sahip olduğu imge etkili olmaktadır. Bu imgenin oluşmasında ise birey ve çevre arasındaki etkileşimde, bireyin kent algısı ve kent tanımlaması süreçleriyle kentin deneyimlenmesi önemli bir role sahiptir (Eraydın, 2016). Başka bir ifadeyle, bireyin yaşadığı kenti deneyimlemesi kent algısının ve kent belleğinin oluşmasında belirgin farklar oluşturmaktadır (Gündoğdu, Kuru ve Özkök, 2016).

Görsel kirlilik; bireylerde hoşnutsuzluk, yorgunluk, bezginlik yaratmakta; düşüncenin yoğunlaşmasını önlemekte ve göz yorgunluğuna ve isteksizliğe yol açmaktadır. Davranış bozuklukları, aşırı sinirlilik, yaşama isteğinde azalma, ruhsal travmalar ve kronik baş ağrılarına sebep olarak bireylerin motivasyonu üzerine olumsuz etkiler yapabilmektedir. Ayrıca fikir çeşitliliğinde azalmaya, kimlik kaybına, kazalara, depresyona, strese ve kaygıya neden olmakta; olumsuz ve kaotik görseller ise özellikle çocuklarda karar verme gücünün azalmasında etkili olmaktadır. Yine koyu renk kombinasyonları algıyı değiştirmekte ve psikolojik ruh halini etkileyebilmektedir (Akın, 2009; Banerjee, 2015, s. 4770; Güney, 2002, s. 249).

$\mathrm{Bu}$ araştırmada, farklı etkinlikler sonucunda mekân üzerinde meydana gelen görsel bozulmalara bağlı olarak ortaya çıkan görsel kirlilik araştırma konusu olarak seçilmiştir. Araştırma sahası olarak Balıkesir kentinin merkezi iş alanı (MİA) seçilmiştir. Araştırmanın amacı Balıkesir kenti MİA'da görsel kirliliğe neden olan unsurların belirlenmesi ve ortaya çıkan bulguların değerlendirilmesidir. Ayrıca, görsel kirlilik ile ilgili yapılan literatür taramasında "görsel kirliliğe yol açan faktörler" ile ilgili bir sınıflandırmaya rastlanılmamıştır. Bu bağlamda görsel kirlilik literatürü dikkate alınarak "görsel kirliliğe yol açan faktörler" ile ilgili bir sınıflama geliştirilmeye çalışılmıştır. Araştırmanın yöntem bölümünde yer alan "görsel kirliliğe yol açan faktörler" sınıflandırmasının; bu araştırmaya özgünlük katacağı, konuyla ilgili gelecekte yapılacak olan araştırmalarda da uygulanabileceği; geliştirilebilir, esnek ve bütüncül bir yaklaşım sunmasından dolayı literatüre katkı sağlayacağı düşünülmektedir.

\section{Yöntem}

Bu araştırmada, nitel araştırma yöntemi tercih edilmiştir. Araştırmada veri toplama yöntemi olarak, doküman incelemesi ve gözlem yolu seçildiği için ve çalışma sonucunda genellenebilir çıkarımlar yerine, belirlenecek farklı çalışma alanlarına ve konuyu ele alış biçimine göre değişen esnek bir yaklaşıma sahip olmasından dolayı nitel bir araştırma yöntemi tercih edilmiştir (Yıldırım, 1999). Araştırmada ilk olarak doküman incelemesi yöntemi (Yıldırım ve Şimşek, 2004) kullanılarak çalışmanın ikincil verilerini oluşturan, görsel kirlilikle ilgili yazılı doküman ve literatür incelenmiştir. Doküman incelemesi yönteminin kullanılmasının nedeni gözlem yoluyla elde edilecek verilerin literatürle desteklenmesidir. Literatürden elde edilen ikincil veriler dikkate alınarak saha çalışmaları gerçekleştirilmiş ve elde edilen birincil veriler kayıt edilmiştir. Saha çalışmaları sırasında gözlem ve fotoğraflama teknikleri kullanılmıştır.

Literatürde görsel kirliliğe yol açan faktörleri sınıflandıran bir çalışmaya rastlanılmadığı için konuyla ilgili ulaşılan kaynaklar ayrıntılı bir şekilde ele alınmış, elde edilen veriler saha gözlemleriyle karşılaştırılarak; görsel kirlilik oluşturan unsurlar birbirleriyle olan ilişkilerine göre, görsel kirliliğe yol açan faktörlerin sınıflandırılması yapılmıştır. Literatürden elde edilen kirlilik türleri, önce kendi aralarındaki ilişkiler dikkate alınıp bir araya getirilmeye çalışılarak taslak bir ana 
sınıflandırma oluşturulmuştur. Bu sınıflandırmaya konu olan türler, Balıkesir MİA'da gerçekleştirilen saha çalışmaları sırasında dikkate alınmıştır. Mekânda nasıl göründükleri ve ne şekilde yer aldıkları da göz önünde bulundurularak ana sınıflar oluşturulmuş ve tanımlamaları yapılmıştır. Görsel kirliliğe neden olan faktörler; yapı, donatı, altyapı ve üstyapı, dolaylı ve diğer olarak ana sınıflara ayrılmıştır (Tablo 1).

Tablo 1. Görsel kirliliğe yol açan faktörler

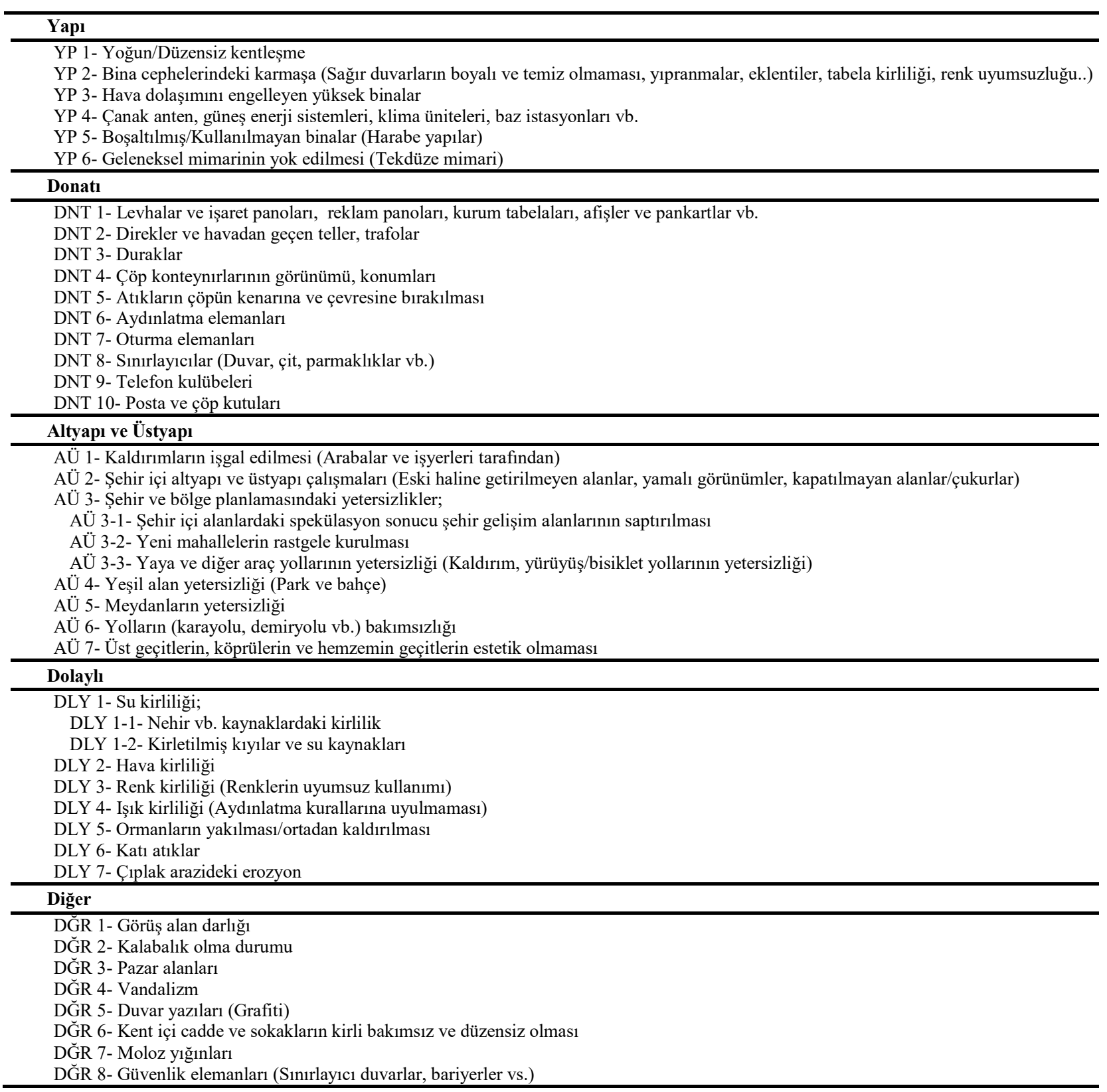

$\mathrm{Bu}$ şekilde bir sınıflandırmanın yapılmasının nedeni ise görsel kirlilik türlerinin anlaşılmasına olanak sağlamak, görsel kirliliğe hangi bakış açılarıyla bakılması gerektiğini ortaya koymak, bu kirliliğin ilişkili olduğu durumların tespitini kolaylaştırmak ve görsel kirlilik konusuna bütüncül bir bakış açısı sunmaktır. Bundan dolayı bu sınıflandırmaya uygun olarak görsel kirliliğe sebep olan unsurlar, konuyla ilgili yayımlanmış olan literatürden hareketle, bu ana sınıfların 
altında bir araya getirilmiştir (Akın, 2009; Alwah, Wen ve Alwah, 2019; Atta, 2013; Banerjee, 2017; Güney, 2002; Güney, 2004; Kaypak, 2019; Önder ve Konakl1, 2002; Voronych, 2013).

Araştırma konusu ile ilgili doküman ve literatür incelendikten sonra saha çalışmaları aşamasına geçilmiştir. Daha önce değinildiği gibi Balıkesir kentinin araştırmacıların uzun yıllardır yaşamakta olduğu bir yer olması ve kentin Merkezi İş̧ Alanı'nda (Harita 1) yaşanan değişimlere ve gelişimlere aşikâr olmaları saha çalışmalarına önemli katkılar sağlamıştır. Kentsel mekân içerisinde yer alan merkezi iş alanları (MİA), kentin bir parçasıdır (Voronych, 2013). MİA, "şehirlerin merkezi kısmında, toplu bir şekle sahip, ticari faaliyetlerin en yüksek yoğunluğa eriştiği ve dikey yönde yükseklik kazandığı alanlar olarak tanımlanabilmektedir" (Aliağaoğlu ve Uğur, 2010, s. 152).

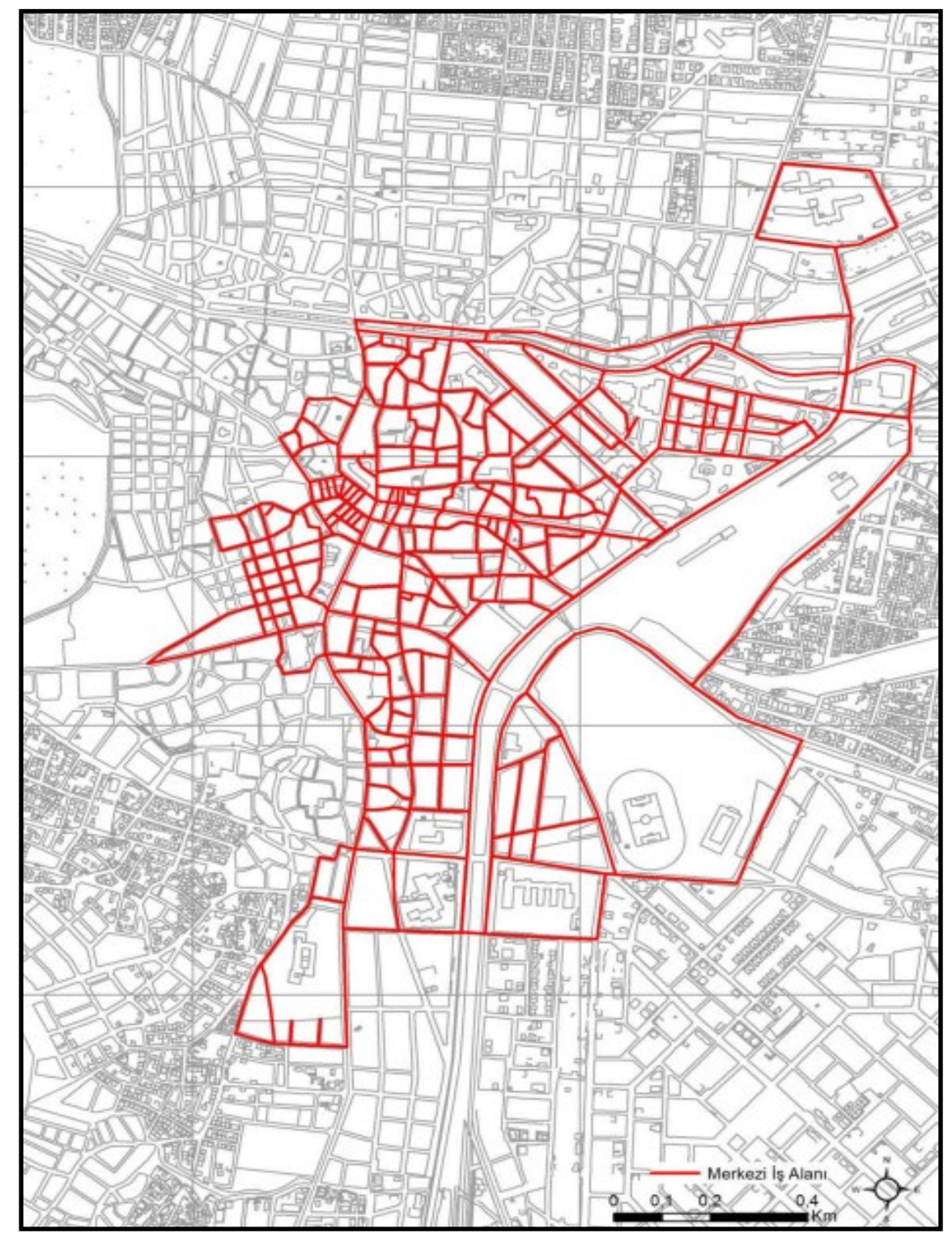

Harita 1: Çalışma alanının haritası/Balıkesir Kenti MİA (Mirioğlu, 2019: 112)

MİA, maksimum iş hacmine, fonksiyonel, toplu ve bireysel kullanımlara ait faaliyetlerin yoğunlaştığı bir alandır. Buna göre Balıkesir kentine ait MİA ise, "kentin merkezi konumunda, toplu bir ticari bölgeye karşılık gelmektedir" (Mirioğlu, 2019, s. 108). Başka bir ifade ile MİA, kentsel mekân içerisinde sahip olduğu işlevsellikten dolayı, bireyin kullanımına açık çeşitli ve fonksiyonel özelliklere sahip ekonomik bir alandır. Mekânda dikey gelişime ve sürekliliğe sahip olması, bireysel ve toplu kullanımların fazla olması ve görsel anlamda daha fazla etkinin görülebilecek olması varsayımından

Examination of Visual Pollution in Central Business District: The Case of Balıkesir Central Business District.

Journal of Urban Academy | Volume: 14 Issue: 2 | ISSN: 2146-9229

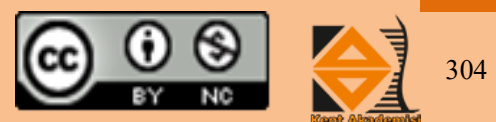


hareketle, Balıkesir Kenti Merkezi İş Alanı çalışma sahası olarak seçilmiştir. Araştırma konusuna bağlı olarak, araştırmacılar yaşadıkları kenti bu kez görsel kirlilik kapsamında gözlemlemişlerdir. MİA'nın farklı bölgeleri, haftanın farklı günleri ve saatlerinde gözlem sahası olarak kullanılmıştır. Bu gözlemler sırasında ilgili literatür aracılı̆̆ıyla oluşturulmuş olan görsel kirliliğe yol açan faktörlerin kategorilerine göre fotoğraflar çekilmiştir.

\section{Bulgular}

Tablo 1'de verilen görsel kirliliğe yol açan faktörlerin kategorileri esas alınarak, Balıkesir kenti MİA'da gerçekleştirilen saha çalışmalarına ilişkin bulgular; her bir alt başlık için ayrı ayrı ele alınmıştır.

\subsection{Yapı}

Balıkesir kent merkezi genel olarak incelendiğinde hızlı kentleşme faaliyetleri sonucunda yoğun/düzensiz bir kentleşme dokusuna sahip olmuştur. Bu durum Balıkesir MİA'da cadde ve sokakların ölçülerinden, bazı yerlerde sokak ve caddelerin fazla dar ve küçük olması ve bazı sokak ve caddelerde binaların birbirine çok fazla yakın olmasıyla da kendisini göstermektedir. Balıkesir kentinin bulunduğu alan, yapılar tarafından bir örtü gibi kaplanmış izlenimi vererek kentleşmedeki yoğunluğu ve düzensizliği göstermektedir (Fotoğraf 1).

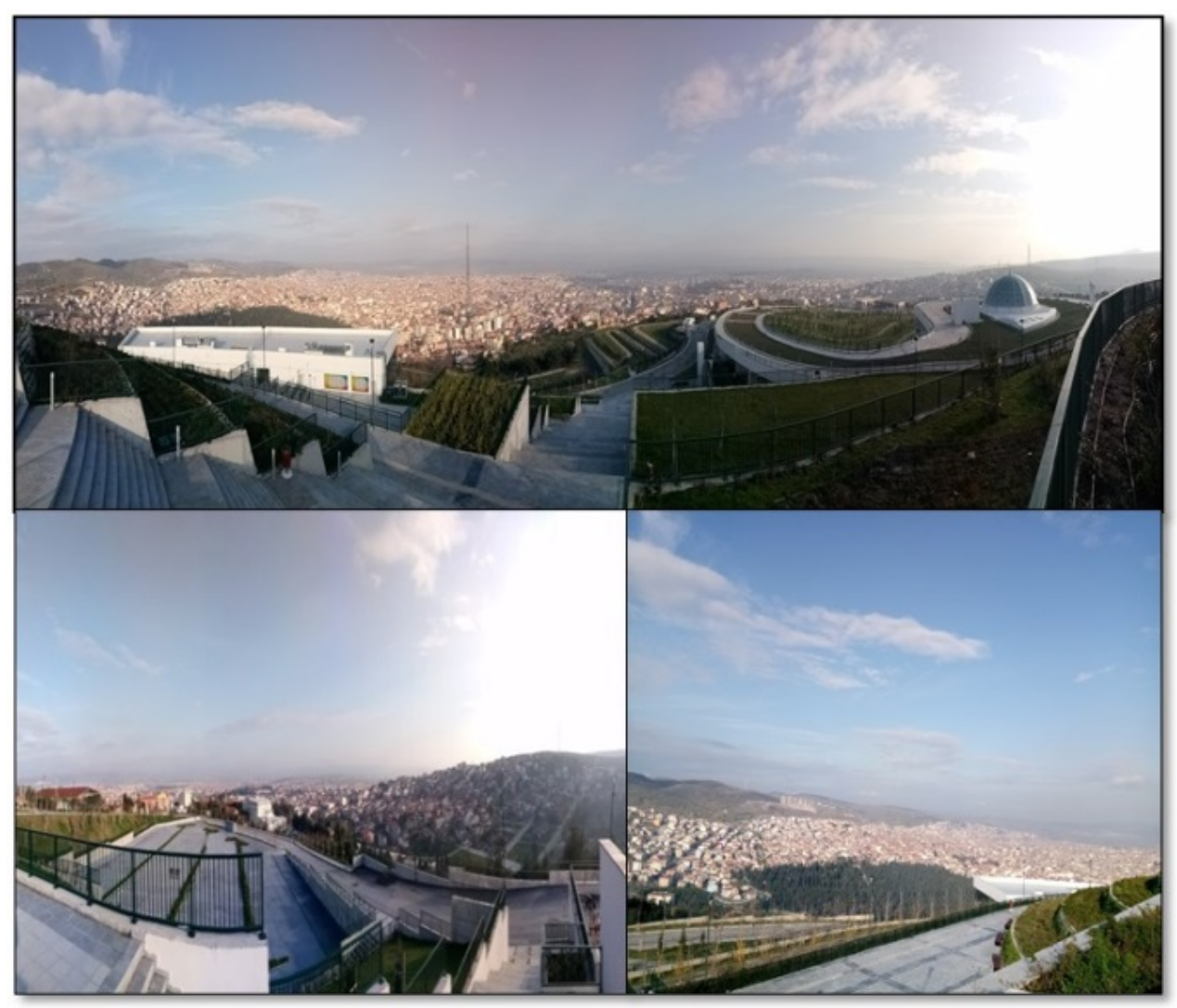

Fotoğraf 1: Balıkesir MİA'daki yoğun/düzensiz kentleşme

Balıkesir MİA'sı görsel kirlilik türlerinden biri olan yapılar bazında ele alındığında; açık bırakılmış olan bina cepheleriyle, boya veya sıvaları yapılmamış olan binalarla, farklı yükseklikteki binaların yan yana varlığıyla karakterize olduğu söylenebilir. Yine bina cepheleri çanak anten, klima üniteleri ve baz istasyonları gibi farklı unsurlarla işgal edilmiş durumdadır (Fotoğraf 2a ve 2b). MİA içeresindeki kafe ve restoranlara ait bacalar, yapıların cepheleri boyunca uzanmaktadır. Yine bu işyerlerine ait yağmurluk ve tentelerin farklı renk, şekil ve boyutlarda olmaları hem görselliği hem de görüş alanı mesafesini etkilemektedir. 
MİA sınırları içerisinde, eskiden sanayi tesisi olarak kullanılan, fakat kentin gelişmesi sonucu yerleşim alanları içerisinde kalarak fonksiyonlarını tamamlamış olan eski sanayi tesisleri bulunmaktadır. Bunlara ek olarak yine MİA içerisinde kullanılmayan binalara ve açık bırakılmış sağır duvarlara rastlamak mümkündür (Fotoğraf 3a). MİA'nın en işlek caddelerden olan Milli Kuvvetler Caddesi'nde ve diğer noktalarda terk edilmiş binalar bulunmaktadır. Yine bu cadde de ve MİA'nın farklı bölgelerinde var olan bazı tarihi yapılar, yeni yapılan betonarme yapılar arasında kalarak aykırı bir görünüm arz etmektedir. Sonuç olarak ortaya uyumsuz yapılardan oluşan bir görünüm çıkmaktadır (Fotoğraf $3 b)$.
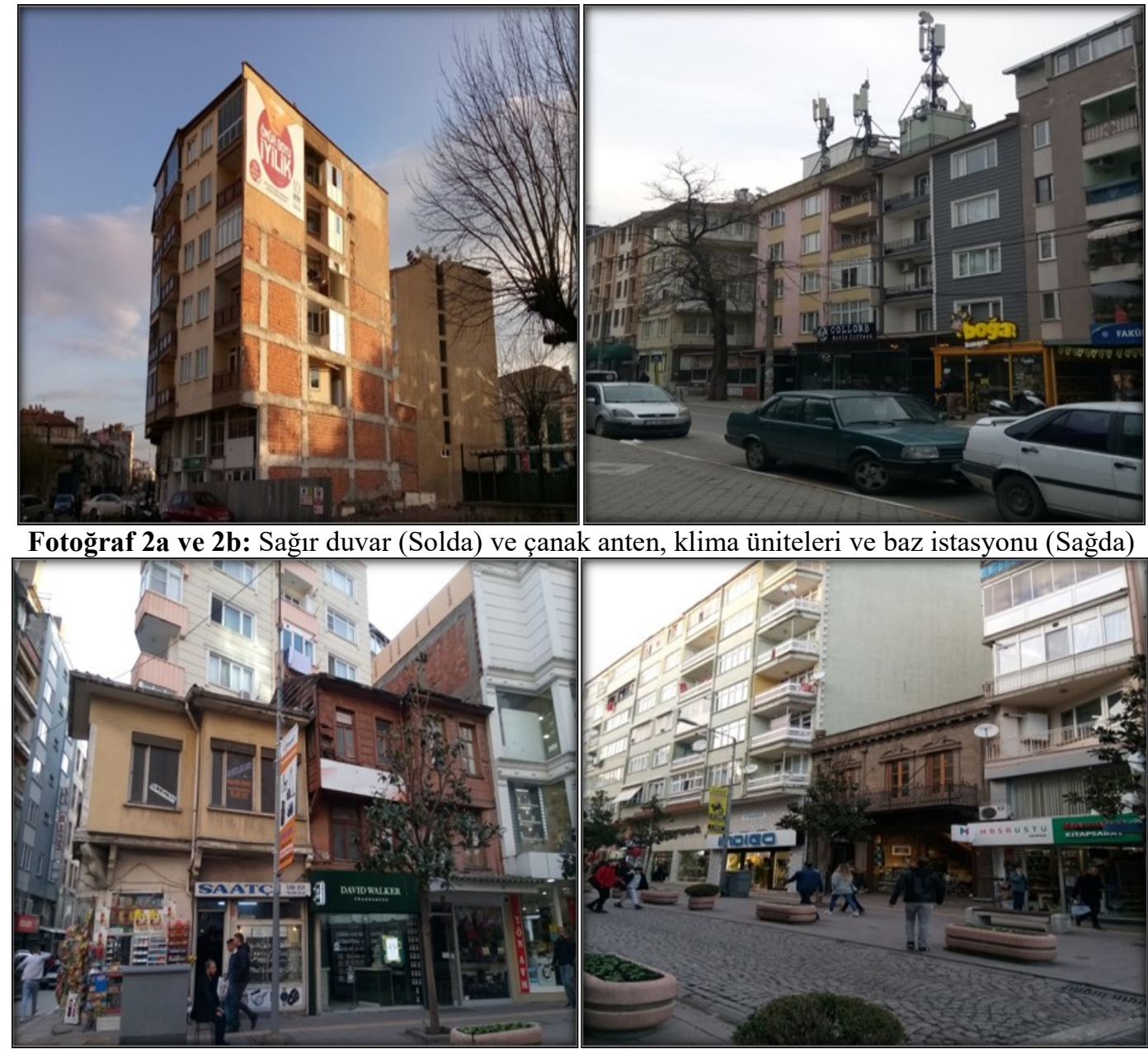

Fotoğraf 3a ve 3b: Atıl durumdaki yapılar (Solda) ve betonarme yapılar arasında kalmış tarihi yapı (Sağda)

\subsection{Donatı}

MİA'lar kentlerde iş alanlarının en yoğun olduğu bölgelerdir. Özellikle hizmet ve ticaret sektörlerinde faaliyet gösteren işyerleri MİA'ya hâkim olan bir görünüm arz etmektedir. Balıkesir kenti MİA'daki görsel kirlilik donatı elemanları açısından değerlendirildiğinde; bu alan içerinde çoğunlukla işyerlerine ve kurumlara ait ilan, pano ve tabelaların hâkim olduğu söylenebilir. İlgili donatı elemanlarının yanlış konumlandırılmaları; kent içerisindeki sürücüleri ve/veya yayaları engellemektedir. Yine uyumsuz öğelerin yan yana konumlandırılması, zarar görmüş panoların değiştirilmemesi, renkleri solmuş ilanlar ve temel tasarım ölçütlerine uymayan grafikler görsel kirlenmelere yol açmaktadır (Bankole, 2013). Balıkesir kenti MİA'sında levha, pano ve ilanların en çok göze çarptığı yerler kentin en işlek yerleri olan Ali Hikmet Paşa Meydanı, Milli Kuvvetler Caddesi, Anafartalar Caddesi ve Kızılay Caddesi'dir. Kent elektriğinin hala direklerle ve havadan iletiminin sağlanması sahip olduğu potansiyel tehlikenin yanında bakımlarının doğru şekilde yapılmamasından dolayı da kentte en görünür kirliliklerden birini oluşturmaktadır (Fotoğraf $4 \mathrm{a}$ ve $4 \mathrm{~b}$ ). Donatı elemanlarının görsel kirlilik olarak algılanmasında Portella'ya (2016) göre iki ana sebep vardır: Birincisi ticari

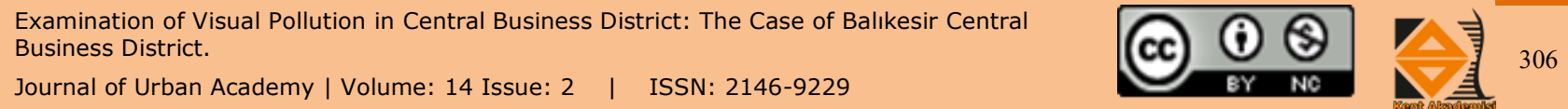


nitelikteki işaretlerin tasarımı ve bina cephelerinin estetik yapısı arasındaki çatışma, ikincisi ise çok sayıda ticari işaretin neden olduğu görsel aşırı yüklenme, boyut, oran, renk, malzeme ve benzeri fiziksel özelliklerin fazla çeşitlilik oluşturmasıdır" (Portella, 2016, s. 22).
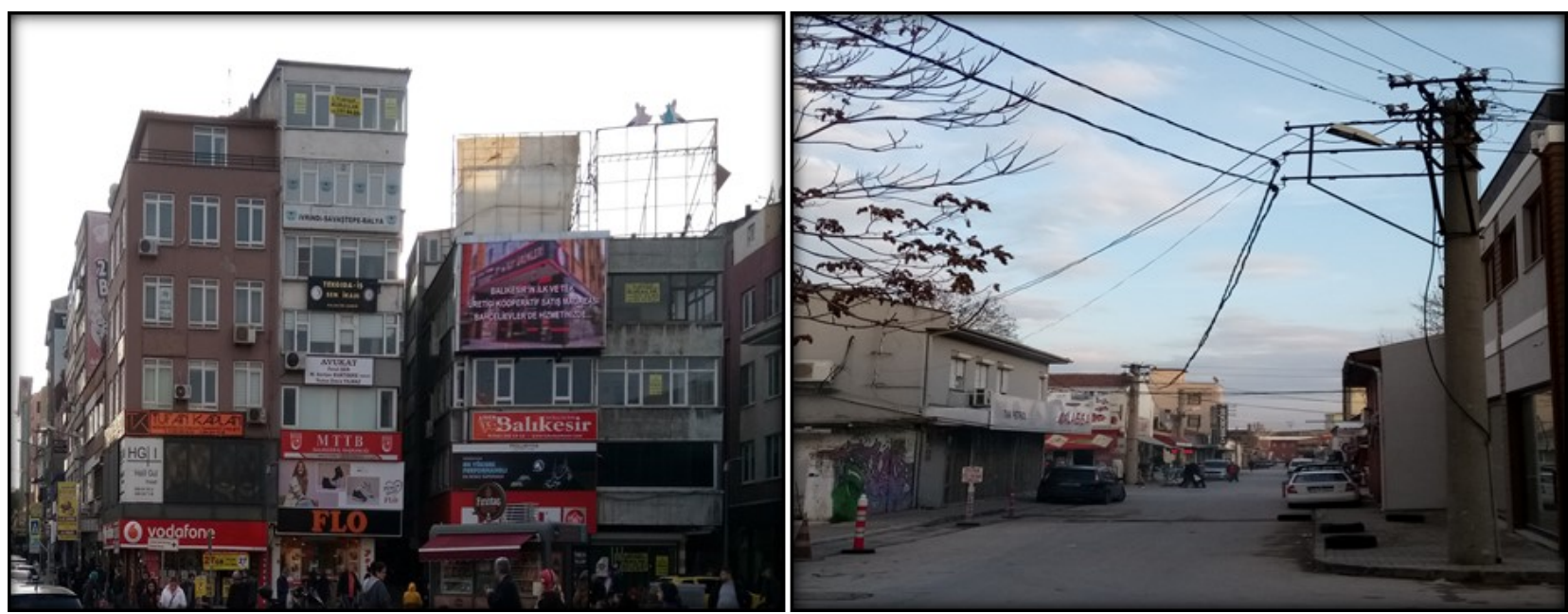

Fotoğraf 4a ve 4b: İlan, levha ve panolar (Solda) ve direkler ve elektrik telleri (Sağda)

MİA sınırları içerisinde kalan dolmuş ve otobüs durakları estetik olarak yetersiz olması, dış görünüşü yenilenmemiş eski durakların varlığı kentsel donatı elemanlarındaki gözlenen görsel kirlilik unsurlarındandır. Ayrıca çoğunlukla duraklara gelişi güzel asılmış olan izinsiz ilan ve broşürlerle kaplı olması da duraklarda göze çarpan kirlilik unsurlarındandır. Çöp konteynırlarının bakımsızlı̆̆ı, eskimesi ve yenilenmemesi başlı başına bir kirlilik durumu oluştururken; bireylerin çöplerini gelişi güzel etrafa atmaları veya çöp kutularının yanlarına bırakmaları da bu durumu desteklemektedir. (Fotoğraf $5 \mathrm{a}$ ve $5 \mathrm{~b}$ ).
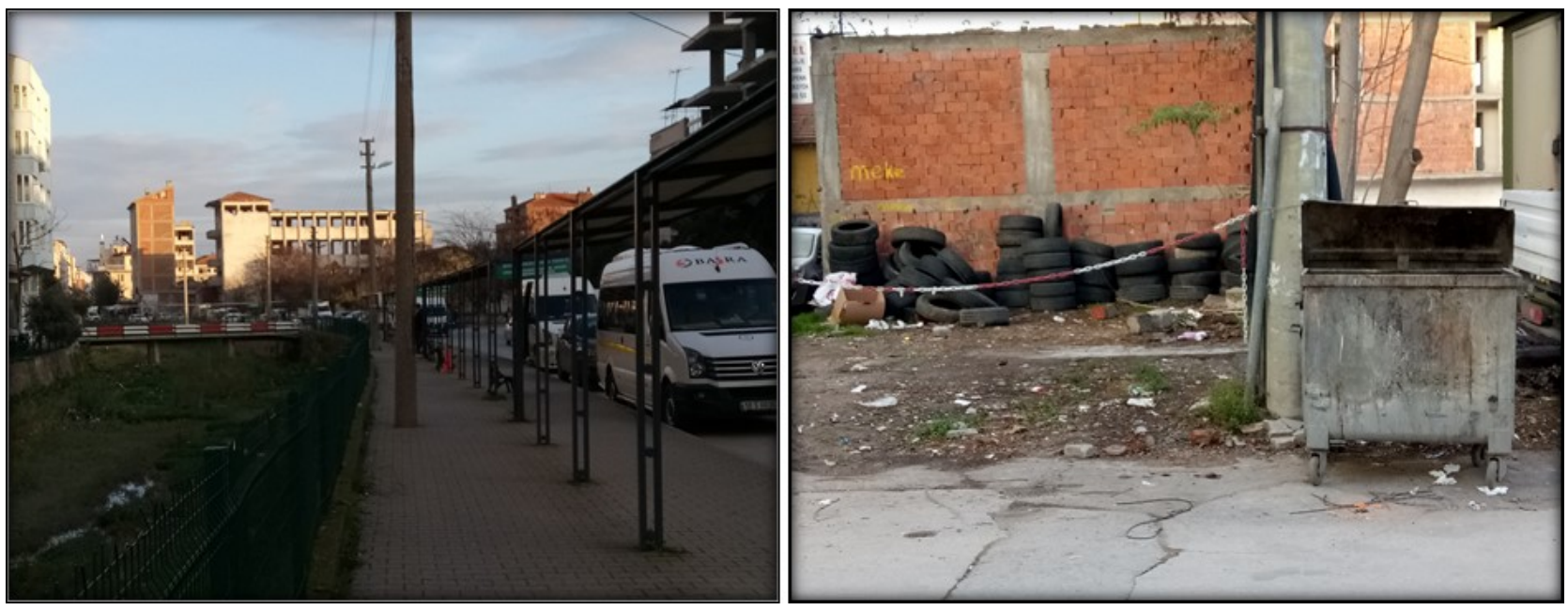

Fotoğraf 5a ve 5b: Duraklar (Solda) ve çöp konteynırlarının konumu ve çevresi (Sağda)

\subsection{Altyapı ve Üstyapı}

MİA'nın üstyapısının planlanmasındaki eksiklik bu alan içerisinde kalan kaldırımların yetersizliğine neden olmaktadır. MİA içerisinde yetersiz düzeyde olan kaldırımlar, ek olarak genellikle de esnaflar tarafından farklı amaçlarla işgale de uğramakta ve kaldırım alanları iyice daralmaktadır. Esnaflar ürünlerini sergilemek veya satmak için (baharatçılar, büfeler, kitapçılar, vb.); lokantalar, kafeler ve çay ocakları ise müşterilerine açık alan sunmak amacıyla yaya yollarını ve kaldırımları işgal etmektedirler. Kaldırım işgalleri hem mekân kullanımını sınırlandırmakta hem de görsel 
kirlenmeye neden olmaktadır (Fotoğraf 6a). Kaldırımlar sadece esnaf tarafından değil inşaat malzemeleri ve molozları tarafindan da işgal edilmektedir (Fotoğraf 6b).
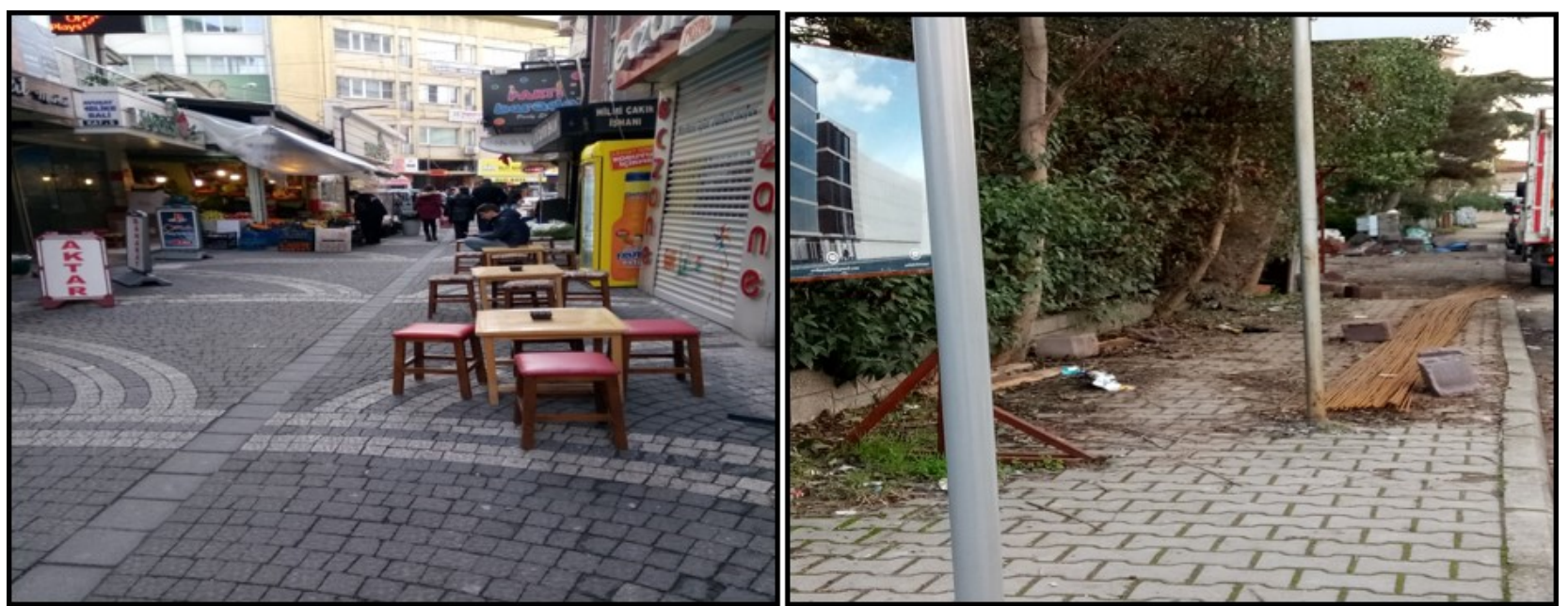

Fotoğraf 6a ve 6b: Kaldırımların esnaf tarafından (Solda) ve inşaat malzemeleri tarafından işgal edilmesi (Sağda)

Kaldırımların tadilatı bir şekilde bırakılması ve eski hallerine dönüştürülmemesi (yamalı görünüm), ayrıca yollarda gerçekleştirilen çalışmalar sonucunda yine yolların eski haline dönüştürülmemesi de görsel kirliliklere sebep olmaktadır. Yine kaldırımların birçok cadde ve sokakta farklı şekillerde ve farklı malzemeler kullanılarak yapılmış olması da görsel kirliliğe neden olmaktadır. MİA’nın çoğu yerinde bisikletler ve motosikletler için gerekli alanlar yeterli değildir. Bu yüzden düzensiz olarak park edilmektedirler.

Şehir planlamasındaki yetersizlikten kaynaklanan cadde ve sokaklardaki yolların şekilsiz olmaları, kaldırımların uygun ölçülerde yapılmaması veya bazı yerlerde kaldırımların olmaması da hem MİA'da hem de kentte görsel kirliliğe neden olmaktadır. Trafiği ve yaya kullanımlarını düzenlemek için yerleştirilen trafik dubalarının deforme olmuş görünümleri ile kaldırımlara araçların park etmemesi için kullanılan beton mantarlar da estetik olmamalarından dolayı görsel kirliliğin başka nedenlerindendir (Fotoğraf 7a).

Kent içerisinde yeşil alanın yetersizliği de önemli bir görsel kirlenme durumudur. Kent merkezinde ve MİA'daki yeşil alanlar yolların refüjlerindeki çimler ve mekân süsleme elemanı olarak kullanılan peyzaj elemanları ve yapay yeşillendirme elemanlarıdır (Fotoğraf 7b). Yeşil alan olarak MİA içerisinde kalan ve kent içinde ortak kullanıma sahip Atatürk Parkı, kent içerisindeki bireylerin yeşil alan ihtiyacı karşılayan tek kaynaktır. İlgili park konumu itibariyle MİA'nın kenar kısmında kalmaktadır. Erişilebilirlik açısından değerlendirildiğinde her birey için erişilebilir bir konumda olmayan Atatürk Parkı buna rağmen yoğun bir kullanım sergilemektedir. 

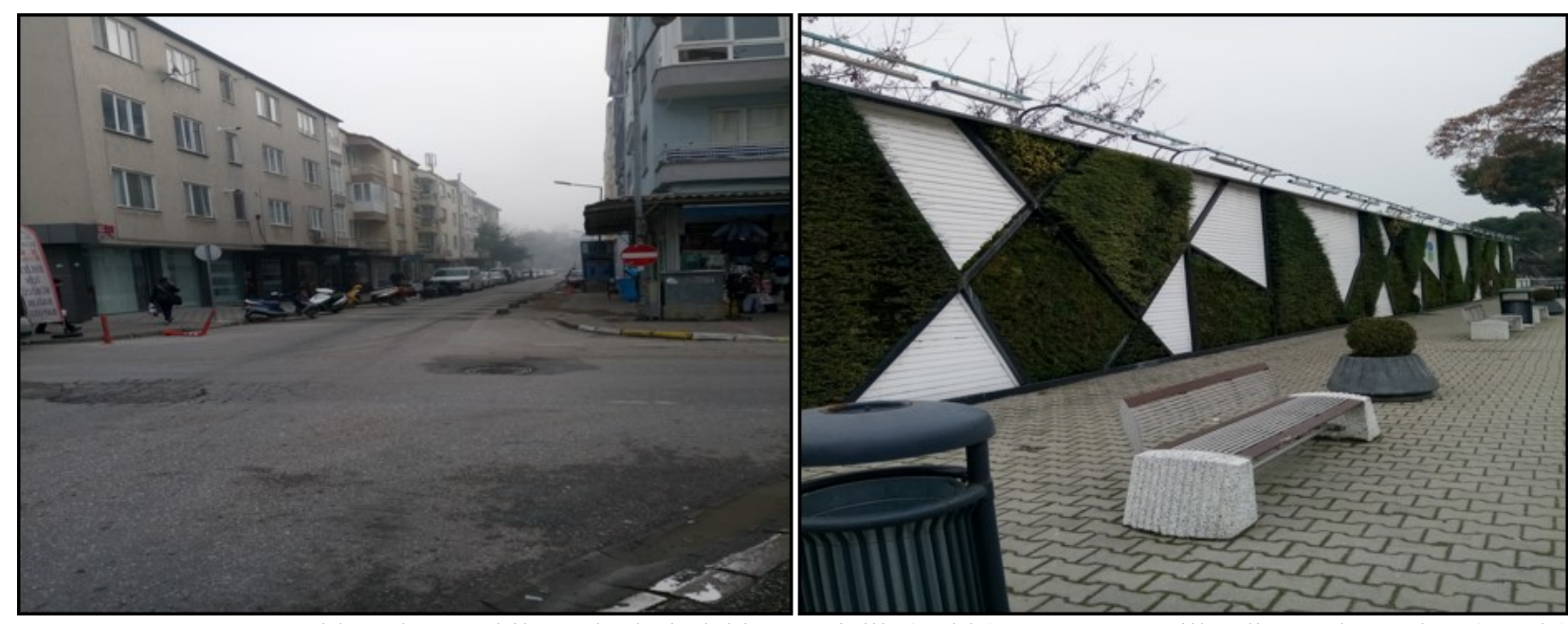

Fotoğraf 7a ve 7b: Kaldırımların şekil ve ölçülerindeki yetersizlik (Solda) ve yapay yeşillendirme elemanları (Sağda)

Meydanlar, kent sakinlerinin yoğun olarak kullandığı mekânlar arasındadır. Ancak meydanlar kentlerdeki düzensiz yapılaşmalardan etkilenmekte, gürültü kirliliği başta olmak üzere birçok problemin yaşandığı alanlar olarak karşımıza çıkmaktadır (Akman, 2020). Bu bağlamda Balıkesir MİA'daki geniş alanlar ve meydanlar değerlendirildiğinde; bunların hem sayı olarak az ve hem de yeteri büyüklükte olmadıkları söylenebilir. Balıkesir MİA içerisindeki meydanlar, özellikle mesai başlama ve bitiş saatlerinde yoğun bir kullanıma/insan trafiğine sahne olmaktadır. Sayı ve kapladıkları alan açısından sınırlı olan Balıkesir MİA'daki meydanlar, diğer taraftan seyyar satıcılar, kafeler, motosikletler ve bisikletler tarafindan işgal edilmiş bir görünüm arz etmektedir (Fotoğraf $8 \mathrm{a}$ ve $8 \mathrm{~b}$ ).
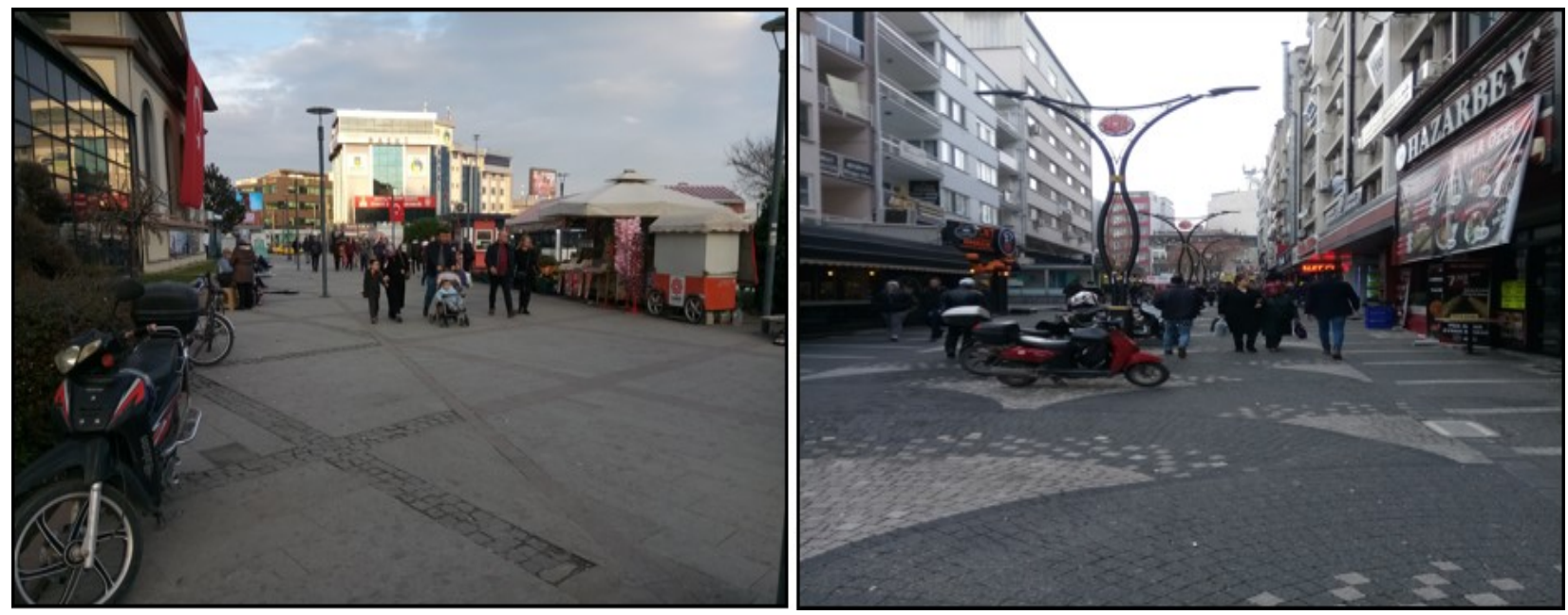

Fotoğraf 8a ve 8b: Meydanların yeterli büyüklükte olmaması (Solda) ve motosikletlerin işgali (Sağda)

Hem kent içerisinden hem de MİA'dan geçen tren yolu bakımsız bir şekildedir. Rayların çevresinin peyzaj düzenlemesi yapılmamış durumdadır. Yine ray hatları boyunca çöplerin biriktiği görülmektedir. Kenti iki parçaya ayırmış şekilde olan tren yolu nedeniyle, MİA ve çevresinde sık sık köprüler ve yaya geçitleriyle karşılaşılmaktadır. Tren yolunun üzerinden geçen köprülerin üzerine koruma amaçlı yapılan tel örgüler ve bunların üzerinin yazılıp boyanması ve köprülerin estetik olmaması görsel olarak kirlilik oluşturmaktadır (Fotoğraf 9a ve 9b). 

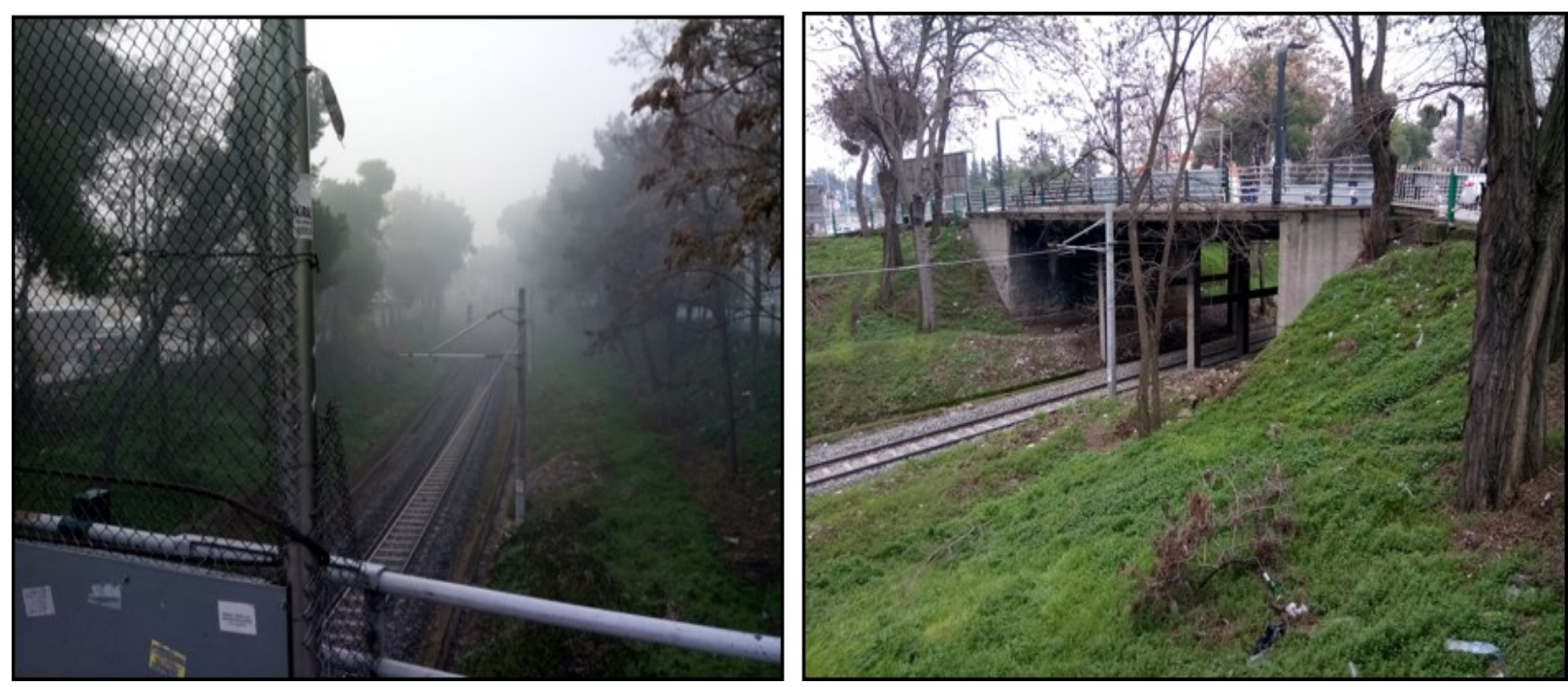

Fotoğraf 9a ve 9b: Tren yolunun bakımsızlığı (Sağda) ve köprünün estetikten uzak görüntüsü (Solda)

\subsection{Dolaylı}

Balıkesir MİA'sının kuzey sınırında yer alan Çay Deresi hem su varlığının bulunmaması hem de kendi haline bırakılmış olması nedeniyle, dere içerisinde çöplerin birikmesine ve yabani bitkilerin yetişmesine neden olmuştur. Ayrıca derenin çevresinde bir peyzaj düzenlemesi yapılmamış olması da başlı başına bir görsel kirlilik unsurudur. Çay Deresi üzerinde de tren yolundaki benzer şekilde köprü ve benzeri geçiş unsurları bulunmaktadır. Ancak geçiş amaçlı kullanılan köprüler ve yaya yolları estetikten uzak bir görünüm arz etmektedir (Fotoğraf 10a ve 10b).
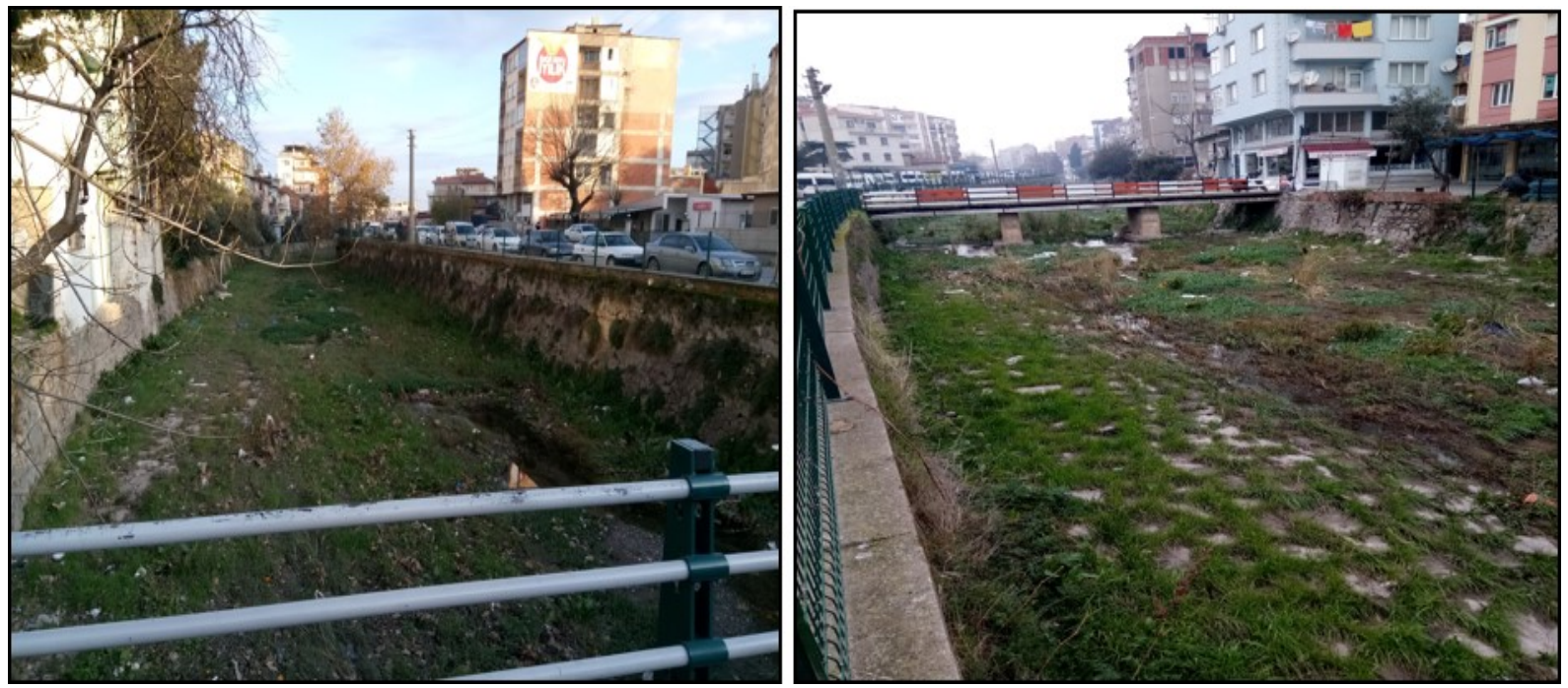

Fotoğraf 10a ve 10b: Çay Deresi ve üzerinde yer alan bir köprü

\subsection{Diğer}

Kaldırımların ve yolların yeterli ölçülerde olmamaları bireylerin kullanımını zorlaştırdı̆̆ı gibi kaldırımlarda; peyzaj bitkileri (ağaçlar, çiçekler ve beton saksılar vb.), işaret levhaları veya aydınlatma direkleri bulunmakta, oturma elemanları da kaldırımlarda yer işgal etmektedir. Kaldırımlardaki bu yoğunluğa, bu alanları kullanan kent sakinleri de eklendiğinde; kaldırımlar hem insanlar hem de donatı elemanları tarafından sık bir kullanıma sahne olmaktadır.

MİA'da bulunan ve MİA'nın en önemli caddeleri arasında yer alan Milli Kuvvetler Caddesi'nde trafik yolu yetersiz, kaldırımlar, levhalar ve reklam panolarıyla kaplı, çevresi ise farklı yükseklikteki betonarme binalar ile çevrilidir. Bu

Examination of Visual Pollution in Central Business District: The Case of Balıkesir Central Business District.

Journal of Urban Academy | Volume: 14 Issue: 2 | ISSN: 2146-9229
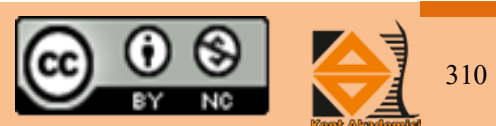
karmaşık yapı MİA'nın en prestijli caddelerinden birisi olması gereken Milli Kuvvetler Caddesi’nin görsel kirliliğe sebep olan unsurlarla çevrelenmesine ve görüş alanın daralmasına neden olmaktadır (Fotoğraf 11a).

Kentin değişik yerlerinde kurulan haftalık pazar alanları gibi MİA içerisinde bulunan Sanat Okulu Caddesi'nde de haftanın her cumartesi günü pazar kurulmaktadır. Kurulan pazar; düzensiz bir yapıdadır ve sürekli genişleme eğilimindedir. Merkezi bir pazar olduğu için çok kalabalıktır. Ancak bu alanın sabit bir pazar yeri olmaması, pazarcılara ait tentelerin ve tezgâhların farklı renk, ölçü ve şekillerde olmasına neden olmuştur (Fotoğraf 11b).

MİA'nın hemen hemen her yerinde rastlanılan bir başka görsel kirlilik durumu ise direklerin, levhaların ve durakların vandalizme uğraması, kırılması, broşür veya ilan yapıştırılması ve duvarların sprey boya ile boyanması saha çalışması sırasında fazlaca rastlanmış diğer kirlilik unsurları arasındadır.
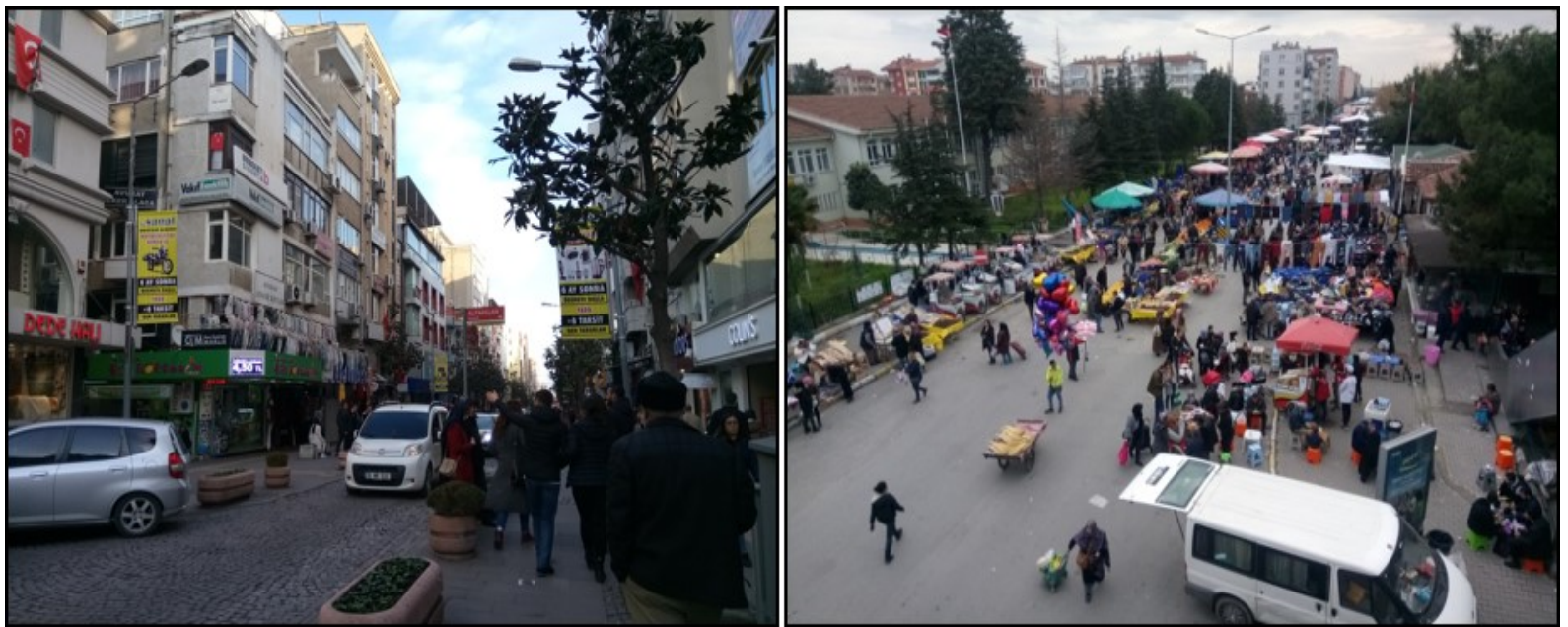

Fotoğraf 11a ve 11b: Kaldırımların peyzaj, donatı elemanlarıyla işgal edilmesi (Solda) ve Cumartesi Pazarı’ndaki düzensizlik (Sağda)

\section{SONUÇ VE TARTIȘMA:}

Diğer çevresel kirlilik türleri gibi görsel kirlilik de bir anda ortaya çıkmamıştır. Çevre bozulmalarına ve kirlenmelerine neden olan süreçte sanayileşme, hızlı nüfus artışı, teknolojik ilerlemeler ve küreselleşme gibi durumların etkileri aşikârdır (Yılmaz ve Sağsöz, 2011). Gün geçtikçe de artan bir şekilde çevre sorunları devam etmektedir. Bozulmanın yapısı ve niteliği ne olursa olsun, bütün kirlilik türleri bireyler için rahatsız edici bir durum oluşturmakta; görsel kirlilikte diğer kirlilik türleri gibi bireylerin sağlığı üzerinde olumsuz etkilere sebep olmaktadır.

Literatür ile saha gözlemleri karşılaştırıldığında, görsel kirlenmeye neden olabilecek unsurlar çalışma alanları ve sınırlarının belirlenmesine göre, mekân ve zamanda farklılık gösterebilmektedir. Balıkesir MİA'da zaman içerisinde kentin ve kenti kullananların ihtiyaç ve istekleri doğrultusunda sürekli değişime uğramıştır. Sonuç olarak MİA'daki iş hacmi, özellikle hizmete yönelik sektörler, önemli derecede artmıştır. Bu gelişmeler MİA'nın bireyler tarafından daha yoğun kullanılmasına neden olmuştur. Kullanıcı sayısının artması görsel kirlilik unsurlarının da MİA'da daha fazla görünür olmasına neden olmuştur. Hizmet sektöründeki artış/hareketlilik; ilan, pano ve tabelalar, kaldırımların işyerleri tarafından işgaline neden olmuştur. Kullanıcı sayısının artması ve yoğun kullanım ise kalabalıklaşmaya yol açmış; bu durum meydanlar ve kaldırımların yetersiz kalmasına neden olmuştur. Ulaşılan bu sonuç çalışma sahasının seçilmesinde öne sürülen "mekânda dikey gelişime ve sürekliliğe sahip olması, bireysel ve toplu kullanımların fazla olması ve görsel anlamda daha fazla etkinin görülebilecek olması varsayımını doğrular niteliktedir.

Görsel kirlenme ve bozulmaların önlenmesinde en önemli rol, bireylerin kendisinde ve toplumsal sorumluluk bilincinde yatmaktadır. Bireyin yaşadığı mekânı sahiplendiği gibi benimsemesi de önem arz etmektedir. Bireylerin sorumluluğu yanında kentlerin yönetilmesi ve denetlenmesinden sorumlu yerel yönetim birimleri de mekânın düzenlenmesinde ve denetlenmesinde idari bir role sahiptir (Alwah, 2019). Altyapı ve üstyapı faaliyetleri esas alınarak düşünüldüğünde, şehir ve bölge planlamasında görsel kirliliğin önlenmesine yönelik çalışmalarda bulunmak kirliliğin önlenmesinde 
başarı getirecek önemli adımlar arasındadır. Bu konuda kentsel tasarım rehberleri de, mekândaki değişimleri düzenlemek, kentsel yeni tasarımların, yenilenmenin ve koruma çalışmalarında kullanılabilecek referans alınacak bir çerçeve sunmaktadır (Karabay Ayataç, 2000). Ayrıca kentsel tasarım rehberleri, kentsel bütünlüğün oluşmasında ve düzenlenmesinde, kent için farklı ölçekte ve farklı amaçlarla hazırlanabilir (Arısu, 2018).

Kentlerdeki görsel kirliliğin ve bozulmaların, özellikle de yapı ile ilgili görsel kirlenmeye neden olan unsurların iyileştirilmesi ve ortadan kaldırılmasında, kentsel dönüşüm uygulamaları önem arz etmektedir (Elmas, 2021). Yine Balıkesir MİA'da olduğu gibi birçok kentimizde yer alan ve genellikle bakımsız/kullanılmayacak durumda olan; görünüşleri itibariyle ciddi görsel kirliliğe sebep olan tarihi binaların da restore edilerek korunması gerekmektedir. Kent bellekleri açısından ciddi öneme sahip bu binalar restorasyon projeleri ile birlikte geleceğe taşınabilirler (Elmas, 2005). Doğayı ve çevreyi korumada geliştirilen ekolojik, sürdürülebilirlik ve bütüncül bakış açılarıyla kentsel planlama çalışmaları yapılabileceği gibi stratejik kentsel planlama kapmasında farklı şehirlerde uygulanmış çalışmalar ve geleceğe yönelik tasarlanmış projeler referans alınarak uygulamaları yapılabilir (Yıldız vd., 2007; Yıldız, 2016).

Bazı donatı elemanlarının gerek konumlandırılması gerekse kullanımında fonksiyonel özelliklerinin yanında estetik değerlerinde dikkate alınarak kullanıma sunulması görsel kirliliğin azalmasında etkili olacaktır. İlan, levha ve panoların kullanımı konusunda, bazı ülke ve şehirlerin aldıkları önlemler bu konuda oluşacak sorunların çözümünde bir öneri niteliğinde düşünülebilir. Örneğin ilan, tabela ve afiş uygulamalarında kısıtlamaya gidilmesi, boyutlarının sınırlandırılması, dış mekân reklamcılığının yasaklanması, aşırı aydınlatma ve neon kullanımının sınırlandırılması gibi uygulamalar bunlar arasındadır (Elena vd., 2012). İlan, reklam panoları ve levhaların daha çok akılda kalabilmek veya dikkat çekici olması açısından kullanılan renklendirmelerin ve fiziksel özelliklerinin ön plana çıkarılması insanları etkileme ve hatırlanma düzeyini önemli ölçüde düşürdüğünü göstermektedir. Ayrıca daha az sayıda ve daha uyumlu renklendirilmiş levhaların daha olumlu değerlendirildiği çalışmalar da bulunmaktadır (Çubukçu, Ekşioğlu Çetintahra ve Sarıca, 2010). Başka bir ifadeyle, görsel kirliğin azaltılmasında ilan ve levhalarda sadeliğe gidilmesi ve daha az sayıda kullanılmaları mekândaki görsel kirliliği azaltmada etkili olacaktır.

Görsel kalitenin arttırılması ve denetlenmesinde grafiti sanatının kullanılması ve bu konuyla ilgili gönüllü bireylerin ve sivil toplum kuruluşlarının yönlendirilmesi de mekânda estetik duygulara uygun görünümlerin oluşmasına ve görsel kirliliğin önlenmesine destek olacaktır. Ayrıca gelişen teknoloji ve internet yapısı sayesinde ilan ve reklamlar, e-ticarette olduğu gibi web sayfaları, telefon uygulamaları ve buna benzer yeni uygulamalar geliştirilerek değerlendirilebilir. Sonuç olarak bireyin ve toplumun, sağlıklı ve mutlu bir çevreye sahip olması için görsel kirliliğe neden olan unsurlar başta olmak üzere diğer kirlilik kaynaklarının da kontrol edilmesi ve doğal çevreye zarar verebilecek davranışlardan sakınılması önem arz etmektedir. Görsel kirliliğin kontrol edilmesi ve denetlenmesinde, görsel kalite değerlendirmesi mekânın estetik değerlerini arttırması ve mekânı kullanan bireylerin yaşam kalitesini olumlu yönde etkilemesinden dolayı uygulanabilecek bir yöntem olabilir (Bogenç vd., 2018).

Kent imajının oluşmasında etkili olan kent algısı da kentte yaşayan bireylerin deneyimleriyle olumlu kent imajlarının oluşturulması sağlanabilir. Balıkesir kentinin şehirsel imajına yönelik yapılan bir çalışmada, yeşil alan yetersizliği, çevre ve su kirliliği gibi görsel kirlenmeye neden olan unsurlar, aynı çalışmada şehir imajının olumsuz elemanları olarak tespit edilmiştir (Aliağaoğlu ve Yılmaz Çildam, 2017).

Bu araştırmada ortaya konan, "görsel kirliliğe yol açan faktörler" sınıflandırmasının; görsel kirlilik konusunda yapılacak olan çalışmalar başta olmak üzere şehir ve mekân planlama çalışmalarına katkı sağlayacağı ve literatürde hali hazırda bir benzeri olmamasından dolayı bu tarz çalışmalar için bir başlangıç noktası olacağı düşünülmektedir. Seçilecek olan yeni çalışma alanlarına ve çalışılan disipline göre tabloda belirtilen kategorilerden hepsi çalışma alanına ya da çalışma konusuna uygulanabileceği gibi tek bir kategori seçilerek de çalışılabilecek bir işlevselliğe sahiptir. Bu konuda araştırmacıya esnek bir bakış açısı da sunmaktadır. Tablonun esnek bir yaklaşıma sahip olmasından dolayı gelecek çalışmalarda tablonun geliştirilmesinde ve iyileştirilmesinde araştırmacıların rolü önemlidir. Konu bir sonraki evrede yine nitel araştırma yöntemleriyle farklı zamanda ve mekânda ele alınabileceği gibi nicel araştırma yöntemleriyle ya da karma (nitel ve nicel) yöntemlerle de ele alınarak zenginleştirilebilir. 


\section{Etik Standart ile Uyumluluk}

Çıkar Çatışması: Yazarlar herhangi bir çıkar çatışmasının olmadığını beyan eder.

Etik Kurul İzni: Bu çalışma için etik kurul iznine gerek yoktur.

\section{KAYNAKÇA:}

Akın, G. (2009). Ekoloji-Çevrebilim ve Çevre Sorunları. Ankara: Tiydem Yayıncılık.

Akman, K. (2020). Kent Meydanlarının Önemi ve Değişen İşlevi. Akademik Düşünce Dergisi, 1 (17-33).

Aliağaoğlu, A. ve Uğur, A. (2010). Şehir Coğrafyası. Ankara: Nobel Yayın Dağıtım.

Aliağaoğlu, A. ve Yılmaz Çildam, S. (2017). Balıkesir'de Şehirsel İmaj: Şehirsel Problemlerin Tespitine Yönelik Bir Araştırma. Doğu Coğrafya Dergisi, 22 (37).

Alwah, A.A.Q., Wen, L. ve Alwah, M.A.Q. (2019). Analysis of Visual Pollution of the Urban Environment in the Old City of Ibb. Third Engineering Conference - Faculty of Engineering, University of Aden, Yemen: Aden.

Anciaes, P. R. (2015). Visual Pollution. İn (Mark Garrett) Encyclopedia of Transportation: Social Science and Policy.. California: SAGE Publications, 1709-1711.

Arısu, S. (2018). Kentsel Tasarım Kavramında Kentsel Tasarım Rehberlerinin Yeri ve Önemi. Kent Akademisi, 11(2), 243-255.

Atta, H. A. (2013). Visual pollution and statistic aldetermination in some of Karrada district main streets/Baghdad. Journal of Engineering, 19(3), 414-428.

Banerjee, S. (2017). A study of visual pollution and its effect on mental health. Scholarly Research Journal for Interdisciplinary Studies, 4 (30), 4768-4771.

Bankole, O. E. (2013). Urban environmental graphics: impact, problems and visual pollution of signs and billboards in Nigeriancities. International Journal of Education and Research, 1(6), 1-12.

Bogenç, Ç., Bekçi, B. ve Üçok, M. (2018). Kent parklarında sosyalleşme mekânlarında ki görsel kalite değerlendirmesi; Rize sahil parkı örneği. In Proceedings of European Conference On Sc1ence, Art \& Culture (ECSAC-2018), Antalya, 381-386.

Bölükoğlu, H. İ. (2003). Görsel Kirlilik ve Sanat Eğitimi. Atatürk Üniversitesi Kazım Karabekir Eğitim Fakültesi Dergisi, 8, 101-112.

Çubukçu, E., Ekşioğlu Çetintahra, G. ve Sarıca, C. (2010). Şehirlerde Görsel kirlilik Önlenebilir mi? Ticari Tanıtım Levhalarının Sayısı ve Rengi Üzerine Deneysel Bir Çalışma. Erciyes Üniversitesi Fen Bilimleri Enstitüsü Dergisi, 26 (4), 387-400.

Elena, E., Cristian, M. ve Suzana, P. (2012). Visual pollution: A new axiological dimension of marketing. Annals of Faculty of Economics, University of Oradea, Faculty of Economics, 1 (2), 820-826.

Elmas, E. S. (2005). Çamlıca-Altunizade-Bağlarbaşı tarihsel çevresi değerlendirme ve Çamlıca'da ahşap bir köşkün koruma projesi. (Yüksek Lisans Tezi). İstanbul: Yıldız Teknik Üniversitesi Fen Bilimleri Enstitüsü.

Elmas, E. S. (2021). Kentsel Dönüşüm Uygulama Stratejisinin Belirlenmesinde Analitik Hiyerarşi Süreci (AHP) Kullanımı: "Sancaktepe İlçesinde Bir Uygulama". Murat Dal (Ed.). Mimarlık Bilimleri ve Teknolojileri içinde (s. 261-293). Fransa: Livre de Lyon.

Görmez, K. (2003). Çevre Sorunları ve Türkiye. Ankara: Gazi Kitabevi. 
Gündoğdu, H. M., Kuru, A. ve ÖZKÖK, M. K. (2016). Kırklareli kent algısı üzerine deneysel bir çalışma. İdealkent Kent Araştırmaları Dergisi, 7(18), 48-79.

Güney, E. (2002). Türkiye Çevre Sorunları. İstanbul: Çantay Kitabevi.

Güney, E. (2004). Çevre Sorunları. Ankara: Nobel Yayın Dağıtım.

Karabay Ayataç, H. (2000). Planlama Sürecinde Kentsel Tasarımın Yeri ve Rolünün Tanımlanması İçin Bir Yöntem Denemesi; Örnekleme Alanı Türkiye. (Doktora Tezi). İstanbul: İstanbul Teknik Üniversitesi Fen Bilimleri Enstitüsü.

Kaypak, Ş. (2019). Kentin Yüzünü Kirleten Görsel Kirlilik; Antakya Örneğinde. [Bildiri]. M. Fatih Bilal Alodalı ve Samira Khadhraoi (Ed.). İKSAD 3. Uluslararası Sosyal Bilimler Kongresi Bildirileri, 8-10 Mart 2019, 294308, İKSAD Publications.

Keleş, R. (1987). Türkiye'de Kentbilim Eğitimi. Ankara: Ankara Üniversitesi Siyasal Bilgiler Fakültesi.

Keleş, R. ve Hamamcı, C. (1998). Çevrebilim. Ankara: İmge Kitabevi Yayınları.

Mirioğlu, G. (2019). Balıkesir Kentinde Kadınların Kamusal Mekân Kullanımı: Feminist Bir Perspektif. (Doktora Tezi). Balıkesir: Balıkesir Üniversitesi Sosyal Bilimler Enstitüsü.

Ögütveren, Ü. B. (2016). Çevre Sorunları ve Politikaları. Eskişehir: Anadolu Üniversitesi.

Önder, S. ve Konaklı, N. (2002). Görsel Kirlilik ve Konya Kenti Örneğinde İncelenmesi Üzerine Bir Araştırma. S.Ü. Ziraat Fakültesi Dergisi, 16(30), 28-37.

Öner, R. (2016). Çevre Sorunları. Aysel Aydın Kocaeren (Ed.). Çevre ve Enerji, 113-155. Ankara: Nobel.

Portella, A. (2016). Visual Pollution: Advertising, Signage and Environmental Quality. New York: Routledge.

Türk, Ş.Ș. (2003). Türkiye'de İmar Planı Uygulamalarında Yeni Bir Sistem Yaklaşımı. (Doktora Tezi). İstanbul: İstanbul Teknik Üniversitesi Fen Bilimleri Enstitüsü.

Voronych, Y. (2013). Visual Pollution of Urban Space in Lviv. Space \& Form, 20, 309-314.

Yıldırım, A. (1999). Nitel araştırma yöntemlerinin temel özellikleri ve eğitim araştırmalarındaki yeri ve önemi. Eğitim ve Bilim, 23(112).

Yıldırım, A. ve Şimşek, H. (2004). Sosyal Bilimlerde Nitel Araştırma Yöntemleri. Ankara: Seçkin.

Yıldız, H., Yıldız, E. ve Önal, G. (2007). Stratejik Kentsel Planlama ve Gelecek Çalışmaları: Dünya Örnekleri ve Yöntemler. (Araştırma Projesi). Projem İstanbul. İstanbul Üniversitesi Mimarlık Fakültesi.

Yıldız, S. G. (2016). Çevre Bilinci ve Eko-Kent Planlaması: Gölbaşı Özel Çevre Koruma Bölgesi Örneği. (Doktara Tezi). Ankara: Ankara Üniversitesi Sosyal Bilimler Enstitüsü.

Yılmaz, S., Bulut, Z. ve Alper, H. (2002). Kentsel Mekânlarda Yaşanan Görsel Kirlilik ve Erzurum Örneği. [Bildiri]. 1. Ulusal Çevre Sorunları Sempozyumu, 749-755.

Yılmaz, D. ve Sağsöz, A. (2011). In the context of visual pollution: Effects to Trabzon city center silhoutte. Asian Social Science, 7 (5), 98-109. 